\title{
Akar Adventif Kedelai Teriradiasi Pada Cekaman Genangan
}

\author{
Belva Ariya Mahendra, Wirdhatul Muslihatin, dan Triono Bagus Saputro \\ Departemen Biologi, Fakultas Sains, Institut Teknologi Sepuluh Nopember (ITS) \\ e-mail: trionobsaputro@bio.its.ac.id
}

\begin{abstract}
Abstrak-Kedelai (Glycine max L.) merupakan komoditas pangan utama selain padi dan jagung yang mengandung protein, minyak, dan karbohidrat tinggi. Kebutuhan yang meningkat tidak diimbangi dengan peningkatan produksinya. Salah satunya karena pengaruh faktor cekaman genangan. Pada penelitian ini, induksi variasi dilakukan dengan metode iradiasi sinar Gamma dengan dosis penyinaran 25Gy, 50Gy, 75Gy, dan 100Gy. Varian hasil iradiasi kemudian diseleksi pada kondisi tergenang dengan konsentrasi air sebesar $100 \%$, $150 \%$, 200\%, dan $250 \%$. Tujuan dari penelitian ini adalah mengetahui pengaruh interaksi antrara cekaman genangan dan iradiasi terhadap jumlah akar adventif pada kedelai. Karakter morfologi yang diamati yang parameter jumlah akar adventif.. Parameter jumlah akar adventif mengalami peningkatan secara signifikan seiring dengan peningkatan konsentrasi penggenangan sedangkan untuk dosis iradiasi tidak memberikan pengaruh terhadap jumlah akar adventif sehingga dapat diketahui bahwa interaksi antara Iradiasi dan Genangan memberikan pengaruh yang tidak signifikan pada parameter akar adventif. Peningkatan jumlah akar adventif tertinggi terjadi pada genangan $250 \%$ dan iradiasi 75 Gy dengan nilai tertinggi 7 , sedangkan untuk rata-rata jumlah akar yang paling rendah dengan pemberian dosis iradiasi 25 Gy pada konsentrasi penggenangan $100 \%$, yaitu 1 .
\end{abstract}

Kata Kunci-Cekaman Genangan, Glycine max L, Iradiasi.

\section{PENDAHULUAN}

$\mathrm{T}$ ANAMAN kedelai (Glycine max L) merupakan salah satu komoditas tanaman pangan penting sebagai sumber utama protein nabati. Kedelai dapat dikonsumsi dalam berbagai produk makanan olahan seperti tahu, tempe dan susu [1]. Tanaman ini sangat penting untuk perbaikan gizi masyarakat jika dibandingkan dengan protein ikan dan susu [1]. Menurut [2] kadar protein biji kedelai lebih kurang 35\%, karbohidrat 35\%, dan lemak 15\%. Di samping itu kedelai juga mengandung mineral seperti kalsium, posfor, besi, vitamin A dan B.

Tingginya manfaat kedelai menyebabkan kebutuhan kedelai dari tahun ke tahun semakin meningkat. Peningkatan permintaan tersebut tidak diikuti dengan peningkatan produksi. Kebutuhan kedelai diperkirakan mencapai 2.2 juta ton/tahun dan diprediksi akan meningkat setiap tahunnya. Namun, hingga tahun 2016 produksi kedelai diperkirakan berada pada kisaran 800-900 ribu ton.

Defisit produksi kedelai tersebut dapat disebabkan oleh kondisi lingkungan. Salah satu faktor utama penentu kondisi lingkungan yang tingginya curah hujan di Indonesia. Periode musim hujan yang lama berpotensi adanya genangan. Terjadinya stress genangan air didefinisikan ketika pori tanah jenuh yang menjadi over kapasitas tanah setidaknya 20\% [3]. Cekaman genangan air (waterlogging) dapat menyebabkan rendahnya pasokan oksigen pada bagian perakaran, penuaan dini sehingga daun klorosis, nekrosis dan gugur serta pertumbuhan tanaman terhambat yang pada akhirnya menurunkan hasil (produktivitas). Besarnya penurunan hasil ini juga tergantung pada varietas kedelai yang ditanam, fase pertumbuhan tanaman, lamanya tergenang, tekstur tanah, adanya penyakit [4][5], and [6].
Rendahnya keragaman atau tidak adanya sumber ketahanan terhadap genangan pada tanaman kedelai menuntut adanya induksi varietas baru tahan kondisi genangan. Varian atau klon yang menunjukkan ketahanan terhadap cekaman genangan dapat digunakan sebagai sumber plasma nutfah yang digunakan untuk persilangan tanaman kedelai. Varietas baru yang tahan genangan dapat digunakan untuk meningkatkan produksi tanaman kedelai nasional [6].

Varietas kedelai yang diamati adalah varietas Grobogan. Varietas ini mempunyai keunggulan yakni umur pendek (76 hari), ukuran polong besar, produksi tinggi, kandungan protein tinggi yakni mencapai 43,9 persen dan daun rontok saat jelang panen [7].

Perakitan varietas unggul memerlukan tetua sebagai sumber gen ketahanan terhadap genangan. Saat ini belum tersedia sumber gen ketahanan terhadap genangan pada kedelai, sehingga perlu dilakukan induksi variasi. Salah satu metode induksi variasi adalah dengan menggunakan sinar gamma. Irradiasi sinar gamma merupakan salah satu cara untuk meningkatkan keragaman genetik tanaman [8]. Iradiasi terbukti dapat meningkatkan produksi kedelai [9]. Perubahan genetik hasil iradiasi bersifat acak sehingga diperlukan seleksi varian secara terarah. Seleksi dilakukan untuk memperoleh tanaman dengan sifat yang diinginkan, termasuk peningkatan ketahanan pada cekaman genangan.

\section{METODE PENELITIAN}

\section{A. Waktu dan Tempat Penelitian}

Penelitian dilakukan pada bulan Januari 2018 - Maret 2018. Analisis morfologi dilakukan di Green House dan Laboratorium Biosains dan Teknologi Tumbuhan, Departemen Biologi, Fakultas Ilmu Alam, Institut Teknologi Sepuluh Nopember Surabaya, Iradiasi benih di Badan Tenaga Nuklir Nasional.

\section{B. Prosedur Kerja}

Penelitian dilakukan sesuai dengan metode sebagai berikut

\section{1) Persiapan Benih}

Bahan yang digunakan meliputi akuades dan biji kedelai yang telah masak secara fisiologis varietas Grobogan yang diperoleh dari Balai Penelitian Kacang-kacangan dan Umbi-umbian (BALITKABI), Malang. Alat yang digunakan adalah wadah untuk perendaman. Langkah yang dilakukan adalah biji kedelai varietas Grobogan direndam selama 6 jam menggunakan akuades lalu dikeringanginkan. Hal ini bertujuan untuk mempercepat proses imbibisi sehingga pertumbuhan tunas menjadi lebih cepat. 2) Persiapan Media Tanam

Pembuatan media tanam dilakukan dengan menyiapkan tanah taman, pupuk organik dan arang sekam dengan komposisi $2 \mathrm{~kg}$ tanah taman, $0,5 \mathrm{~kg}$ arang sekam dan $0,5 \mathrm{~kg}$ pupuk organik sehingga didapatkan berat total sebanyak $3 \mathrm{~kg}$.

3) Pengukuran Kapasitas Lapang

Pengukuran kapasitas lapang bertujuan untuk menentukan volume penyiraman sebagai patokan pemberian taraf penggenangan yaitu dilakukan dengan cara media tanam dalam polybag disiram dengan air sampai menetes kemudian didiamkan selama kurang lebih 3 hari sampai tidak ada air yang menetes lagi. Kemudian media tanam ditimbang berat basah dan berat keringnya. Berat basah ditimbang setelah tidak ada air yang menetes lagi dari dalam polybag. Berat kering ditimbang setelah media tanam dioven 
Tabel 1.

Rata-rata Jumlah Akar Adventif Tanaman Kedelai dengan Perlakuan Dosis Iradiasi dan Konsentrasi Penggenangan

\begin{tabular}{|c|c|c|c|c|c|}
\hline \multirow{2}{*}{$\begin{array}{c}\text { Penggenangan } \\
(\%)\end{array}$} & \multicolumn{5}{|c|}{ Dosis Iradiasi (Gy) } \\
\hline & 0 & 25 & 50 & 75 & 100 \\
\hline 0 & $1,33 \pm 1,15^{b}$ & $1,33 \pm 1,53^{\mathrm{b}}$ & $2 \pm 1^{\mathrm{ab}}$ & $2 \pm 1^{\mathrm{b}}$ & $1,67 \pm 2,89^{\mathrm{ab}}$ \\
\hline 100 & $1,67 \pm 2,08^{\mathrm{ab}}$ & $1 \pm 1^{\mathrm{b}}$ & $1,67 \pm 2,08^{\mathrm{ab}}$ & $2,33 \pm 0,58^{\mathrm{ab}}$ & $2 \pm 1,73^{\mathrm{ab}}$ \\
\hline 150 & $4,33 \pm 0,58^{\mathrm{ab}}$ & $1,33 \pm 2,3^{\mathrm{ab}}$ & $1,33 \pm 1,53^{b}$ & $2,33 \pm 1,41^{b}$ & $2,33 \pm 2,52^{\mathrm{ab}}$ \\
\hline 200 & $6 \pm 2^{\mathrm{ab}}$ & $1,67 \pm 2,89^{\mathrm{ab}}$ & $3,33 \pm 2,08^{\mathrm{ab}}$ & $3,6 \pm 0,58^{\mathrm{ab}}$ & $2,33 \pm 2,08^{\mathrm{ab}}$ \\
\hline 250 & $6 \pm 2,65^{\mathrm{ab}}$ & $4 \pm 1,73^{\mathrm{b}}$ & $4,67 \pm 1,15^{\mathrm{ab}}$ & $7 \pm 1^{\mathrm{a}}$ & $2,33 \pm 2,081^{\mathrm{ab}}$ \\
\hline
\end{tabular}

Keterangan : Superskrip yang berbeda pada semua kolom menunjukkan perbedaan yang signifikan $(\mathrm{P}<0,05)$

pada suhu $105^{\circ} \mathrm{C}$ selama 24 jam sampai didapatkan berat konstan. Kebutuhan Air berdasarkan Kapasitas Lapang dihitung dengan rumus:

$\mathrm{KL}(\%)=\frac{\mathrm{Tb}-\mathrm{Tk}}{\mathrm{Tk}} \times 100 \%$

Keterangan :

$\mathrm{KL}=$ Kapasitas Lapang

$\mathrm{Tb}=$ Berat Basah

$\mathrm{Tk}=$ Berat Kering

4) Iradiasi Biji

Biji kedelai disterilisasi pada bagian permukaan dengan $70 \%$ ethanol selama 2 menit dan $1 \% \mathrm{NaOCl}$ selama 5 menit. Kemudian biji diletakkan pada cawan petri dan di wrap. Lalu dilakukan pemaparan sinar Gamma pada beberapa level, yaitu 25Gy, 50Gy, $75 \mathrm{~Gy}$, dan 100Gy masing-masing sebanyak 350 biji untuk tiap konsentrasi iradiasi yang dilakukan di Badan Teknologi Atom Nasional (BATAN).

5) Persiapan biji

Bahan yang digunakan meliputi akuades dan biji kedelai yang telah masak secara fisiologis varietas Grobogan yang diperoleh dari Balai Penelitian Kacang-kacangan dan Umbi-umbian (BALITKABI), Malang. Alat yang digunakan adalah wadah untuk perendaman. Langkah yang dilakukan adalah biji kedelai varietas Grobogan direndam selama 6 jam menggunakan akuades lalu dikeringanginkan. Hal ini bertujuan untuk mempercepat proses imbibisi sehingga pertumbuhan tunas menjadi lebih cepat.

6) Perlakuan Cekaman Genangan

Tanaman kedelai yang telah diaklimatisasi selama 7 hari diberi perlakuan cekaman genangan sesuai dengan perhitungan yang diperoleh. Penggenangan dilakukan selama 14 hari sesuai pada penelitian [9] pada semua taraf perlakuan dengan cara pemberian air pada masing-masing polybag sesuai dengan konsentrasi yang telah ditentukan berdasarkan hasil penghitungan kapasitas lapang, dan dilakukan pemberian air setiap harinya sesuai dengan penghitungan kapasitas lapang pada awal cekaman genangan. 7) Pemanenan

Pemanenan dilakukan setelah kurang lebih 14 hari masa perlakuan cekaman genangan selesai. Tanaman diambil dan dibersihkan dari sisa tanah menggunakan air kemudian ditiriskan. Selanjutnya dimasukkan ke dalam plastik dan diberi label. Kemudian disimpan dalam freezer untuk selanjutnya dilakukan analisis.

8) Pengamatan pertumbuhan kedelai

Pengukuran pengamatan pertumbuhan dilakukan dengan pengamatan dan penghitungan akar adventif.

9) Pengamatan Morfologi

Pengamatan morfologi dilakukan dengan mengambil satu tanaman dari tiap satuan percobaan termasuk kontrol. Variabel pertumbuhan yang diamati meliputi tinggi tanaman, jumlah cabang, luas daun, berat basah dan berat kering, panjang akar, dan akar adventif.

\section{Rancangan Penelitian}

Percobaan dilakukan dengan menggunakan Rancangan Acak Faktorial dua faktor dengan 3 kali ulangan. Faktor tersebut adalah konsentrasi penggenangan dengan 5 taraf perlakuan (penggenangan $0 \%, 100 \%, 150 \%, 200 \%$, dan $250 \%$ ) dan dosis iradiasi dengan 5 taraf perlakuan (0 Gy, 25 Gy, 50 Gy, 75 Gy, dan 100 Gy) .

\section{Analisis Data}

Data hasil pengamatan dianalisa secara deskriptif dan kuantitatif yang didukung dengan analisis statistik. Data yang dianalisa secara deskriptif adalah produk PCR dengan penanda ISSR kedelai hasil iradiasi dengan perlakuan penggenangan, sedangkan analisa pertumbuhan tanaman dianalisa secara statistik dengan analisis keragaman (ANOVA) two-way dengan taraf signifikan $(\alpha) 0,05 \%$ untuk mengetahui pengaruh perlakuan pada parameter yang diamati. Hipotesis yang digunakan adalah sebagai berikut:

$\mathrm{H}_{0}$ :genangan tidak berpengaruh terhadap karakter morfologis kedelai (Glycine max) varietas Grobogan.

$\mathrm{H}_{1}$ :genangan berpengaruh terhadap karakter morfologis kedelai (Glycine max) varietas Grobogan.

Selanjutnya, apabila $\mathrm{H}_{1}$ diterima maka dilakukan uji lanjutan yaitu uji Duncan Multiple Range Test (DMRT) 5\% dengan program SPSS 16.0 untuk membandingkan perlakuan genangan yang paling efektif diantara tiap-tiap perlakuan.

\section{HASIL DAN PEMBAHASAN}

Pengaruh Interaksi Iradiasi dan Cekaman Genangan Terhadap Pertumbuhan Tanaman Kedelai (Glycine max. L). Pertumbuhan tanaman digunakan sebagai indikator untuk mengetahui karakteristik tanaman dan hubungannya dengan faktor lingkungan. Telah dilakukan penelitian, untuk mengetahui tanggapan tanaman kedelai varietas Grobogan terhadap penggenangan pada vase pertumbuhan vegetatif. Hasil penelitian menunjukkan konsentrasi penggenangan secara nyata berpengaruh pada beberapa parameter akar adventif.

Akar adventif adalah salah satu indikator bahwa tanaman mengalami kondisi cekaman genangan, menunjukkan bahwa tanaman tersebut beradaptasi atau toleran terhadap genangan [10]. Menurut [11] munculnya akar adventif berfungsi untuk menjaga kelangsungan penyediaan air dan mineral serta menggantikan fungsi dari akar utama yang tidak bisa menyerap oksigen dengan maksimal pada kondisi cekaman genangan.

Pembentukan akar adventif dipengaruhi oleh adanya kondisi genangan pada lahan tanam, hal ini sesuai dengan pernyataan [12] apabila terjadi kondisi cekaman genangan, tanaman kedelai akan menumbuhkan akar adventif dan aerenkim yang berfungsi untuk mengalirkan oksigen dari batang ke akar. Hasil Uji kuantitatif dengan ANOVA diketahui bahwa faktor cekaman genangan berpengaruh terhadap jumlah akar adventif tanaman dengan nilai $\mathrm{p}$ $=0,000(\mathrm{p}<0,05)$. Hasil uji Tukey menunjukkan bahwa rata-rata jumlah bintil akar yang paling tinggi dengan pemberian dosis iradiasi 75 Gy pada konsentrasi penggenangan $250 \%$, yaitu 7 , sedangkan untuk rata-rata jumlah akar yang paling rendah dengan pemberian dosis iradiasi 25 Gy pada konsentrasi penggenangan $100 \%$, yaitu 1 .

Pada kondisi penggenangan $250 \%$ dengan dosis iradiasi $75 \mathrm{~Gy}$, merupakan kedelai yang tergenang mampu membentuk akar adventif paling banyak diantara lainnya [13]. Hal ini terjadi karena tanaman memiliki daya adaptasi terhadap bentuk akar lateral dan akar adventif. Pada saat tanaman dalam keadaan hipoksia (kekurangan $\mathrm{O}^{2}$ ), akar adventif akan terbentuk pada bagian atas akar mendekati permukaan tanah dimana tekanan oksigen tinggi. Menurut [14] kedelai beradaptasi terhadap genangan dengan 
mengalokasikan fotosintesis dengan cara mengembangkan akar adventif dan akar adventif dapat mengurangi pengaruh buruk genangan dengan memperluas area perakaran ke udara, meningkatkan respirasi aerob, dan mengoksidasi rizosfer.

\section{KESIMPULAN}

Interakasi antara cekaman genangan dan iradiasi sinar gamma tidak berpengaruh secara signifikan pada pengamatan parameter jumlah akar. Cekaman genangan pada tanaman kedelai varietas Grobogan mempengaruhi pertumbuhan tanaman. hal ini ditunjukkan dengan adanya peningkatan jumlah akar adventif. Nilai akar adventif yang paling tertinggi terjadi pada genangan $250 \%$ dosis iradiasi 75 Gy dengan nilai tertinggi 7 , sedangkan untuk rata- rata jumlah akar yang paling rendah dengan pemberian dosis iradiasi 25 Gy pada konsentrasi penggenangan $100 \%$, yaitu 1. Hal ini menunjukkan bahwa penggenangan mempengaruhi jumlah akar adventif yang terbentuk untuk menjaga kelangsungan penyediaan air dan mineral serta menggatikan fungsi dari akar utama yang tidak bias menyerap oksigen dengan maksimal pada kondisi cekaman genangan.

\section{DAFTAR PUSTAKA}

[1] Suprapto, Bertanam Kedelai. Jakarta: Penebar Swadaya, 2004.

[2] Suprapto, Bertanam Kedelai, 10th ed. Jakarta: Penebar Swadaya, 2001.

[3] I. Alam, D. G. Lee, K. H. Kim, C. H. Park, S. A. Sharmin, and H. Lee, "Proteome Analysis of Soybean Roots Under Waterlogging Stress at An Early Vegetative Stage," J. Biosci, vol. 35, pp. 49-62, 2010.

[4] R. K. Sairam, D. Kumutha, K. Ezhilmathi, P. S. Deshmukh, and G. C. Srivastava., "Phisiology and biochemistry of waterlogging tolerance in plants," Biol. Plant, vol. 52, p. 401-412, 2008

[5] C. Riche, "Identification of soybean cultivars tolerance to waterlogging through analyses of leaf nitrogen concentration," 2004.

[6] R. T. Hapsari and M. M. Addie, "Peluang Peakitan dan Pengembangan Kedelai Toleran Genengan," J. Litbang Pertan., vol. 29 , no. 2,2010

[7] Balai Penelitian Tanaman Kacang-kacangan dan Umbi-umbian (Balitkabi), "Deskripsi Varietas Kacang-Kacangan dan UmbiUmbian," Malang, 2014.

[8] D. S. Hanafiah, S. Trikoesoemaningtyas, and D. W. Yahya, "Induced mutations by gamma ray irradiation to Argomulyo soybean (Glycine max) variety," Bioscience, vol. 2, no. 3, pp. 121-125, 2010

[9] J. Mudibu, K. K. C. Nkongolo, A. Kalonji-Mbuyi, and V. K. Roger., "Effect of gamma irradiation on morpho agronomic characteristics of soybean soybean (Glycine max L.)," Am. $J$. Plant Sci., vol. 3, pp. 331-337, 2012.

[10] Y. Jitsuyama, "Hypoxia-Responsive Root Hydraulic Conductivity Influences Soybean Cultivar-Specific Waterlogging Tolerance," Am. J. Plant Sci., vol. 8, pp. 770-790, 2017.

[11] M. J. Sembiring, R. I. M. Damanik, and L. A. M. Siregar., "Respon Pertumbuhan Beberapa Varietas Kedelai (Glycine max L. Merrill) pada Keadaan Tergenang terhadap Pemberian GA3," J. Agroteknologi, vol. 4, pp. 2331-2340, 2016.

[12] K. Suematsu, T. Abiko, V. L. Nguyen, and T. Mochizuki., "Phenotypic variation in root development of 162 soybean accessions under hypoxia condition at the seedling stage," Plant Prod. Sci., vol. 20, pp. 323-335, 2017.

[13] W. Ralph, "Soybean respond to controlled waterlogging," Rural Res, vol. 120, pp. 4-8, 1983

[14] M. Bacanamwo and L. C. Purcell., "Soybean root morphological and anatomical traits associated with acclimation to flooding," Crop Sci, vol. 39, pp. 143-149, 1999. 